\title{
Assessment Process of Fabric Appearance for Black Fabric
}

\author{
Maru Hiroki ${ }^{\text {a }}{ }^{*}$, Saito Shoji ${ }^{\text {b }}$, Kanai Hiroyuki ${ }^{\text {b }}$, Nishimatsu Toyonori ${ }^{\text {b }}$ \\ ${ }^{a}$ Interdisciplinary Graduate School of Science and Technology, Shinshu University, 3-15-1 Tokida, Ueda, Nagano 386-8567, Japan \\ ${ }^{\mathrm{b}}$ Faculty of Textile Science and Technology, Shinshu University, 3-15-1 Tokida, Ueda, Nagano 386-8567, Japan
}

Received 9 February 2016; accepted for publication 21 June 2016

\begin{abstract}
Investigation on a hierarchical structure of fabric appearance-related perceptual and affective experience afford further understanding how to approach the establishment of assessment on fabric appearance. In this study, we tried to representing the assessment process based on three layers (basic appearance, middle appearance and upper appearance). And the assessment process was defined based on causal relationship among the 27 adjectives resulting from sensory assessment with 6 black fabrics by experts panels. Conducting factor analysis enabled the middle appearance to define with adjectives included in basic appearance. As a result, it was found that the middle appearance was constituted with 4 factors, (i.e., 'macroscopic or microscopic brightness', 'softness', and 'roughness'). Furthermore, establishing multiple regression equation enabled the upper appearance to define by factors involved with the middle appearance. It was found that the upper appearance was impacted by magnitude of 'macroscopic brightness' negatively, and impacted by magnitude of 'softness' and 'microscopic brightness' positively.
\end{abstract}

Key Words : Fabric appearance, Black fabric, Sensory evaluation

\section{黒色織物における視覚的風合い評価プロセスの客観的表現}

\author{
丸弘樹 ${ }^{\mathrm{a}, *}$, 齋藤奨司 ${ }^{\mathrm{b}}$, 金井博幸 ${ }^{\mathrm{b}}$, 西松豊典 ${ }^{\mathrm{b}}$ \\ a 信州大学大学院総合工学系研究科, ${ }^{b}$ 信州大学繊維学部
}

\section{1.はじめに}

風合い (Texture) とはなにかという問題は, これまでに多 くの研究者により論じられてきている [1-3]. これらを踏ま えた上で風合いを考えてみると, 布の風合いとは, 「人が感 覚器官を通して知覚する布の物性」であり, 想定する衣服の 利用用途や形態によってそれぞれの生地に求められる風合い の特徵は異なるといえる。 また, 従来の風合い研究では, と りわけ触知覚を通して知覚される風合い（触知覚的風合い, Fabric Hand) が対象とされ, 風合い評価に用いる形容語に関 する研究 $[4,5]$, 風合いの官能検査手法 $[6,7]$ と風合い評価 の定量化 (尺度化) 手法に関する研究 $[8,9]$, 風合い評価構 造に関する研究 [10-12], 布の物理特性の計測手法に関する 研究 [13-15], 風合い評価の官能量と物理特性との対応に関 する研究 $[8,16-18]$ の観点で研究され, 触知覚的風合いの
体系化が行われてきた。 その最たる成果が, 布の力学的特性 より触知覚的風合いを計量化する KES (Kawabata Evaluation System) の確立 [12] であり, 繊維業界に広く普及するに至っ た。

一方, 冠婚葬祭に着用される礼服 (ブラックフォーマル ) 設計のために製織される黑色織物に限定して風合いを考えた 場合, 外観の審美性が重要となることから衣服の形状や生地 のドレープだけでなく, 視覚を通して知覚される風合い（視 覚的風合い, Fabric Appearance) が生地に強く求められる. しかし, 視覚的風合いは, 触知覚的風合いのように体系化さ れていないのが現状であり, 生産者間においても視覚的風合 いに対する評価規範が確立しているとはいえない. 先行研究 から視覚的風合いの現状について考えると, 風合い評価に用 いる形容語に関する研究として, Brand[5] は布の審美性を表 現する多数の風合い形容語を挙げて視覚的風合い評価に用い

* 連絡先 : 信州大学繊維学部繊維・感性工学系先進絨維工学課程 386-8567 長野県上田市常田 3-15-1 E-mail : kanai@shinshu-u.ac.jp, Tel : +81-268-21-5614, Fax : +81-268-21-5614 
るべき形容語を提案した。風合いの官能検査手法と風合い評 価の定量化 ( 尺度化) 手法に関する研究として, 金井ら [19] はBrandの形容方法を基に黒色織物の三原組織を対象とした 視覚的風合い評価を行い, 統計的手法によって視覚的風合い の評価因子の抽出を試みた。風合い評価構造に関する研究に ついては，研究例がそしく評価構造に言及したものはみられ ない. また, 布の物理特性の計測手法として, 布の光学的特 性に基づく手法 [20-23] が提案されているが, 風合い評価の 官能量と物理特性との対応付けについては課題が残されてい る.このように視覚的風合いは, 体系化プロセスにおいて未 確立な要素が多分に山積している。

以上のことから, 視覚的風合いの体系化の第一段階として, 本研究では黒色織物における視覚的風合い評価プロセスを客 観的に表現することを目的とした，評価プロセスを客観的に 表現することは, 視覚的風合いの解明やその評価構造モデル の提案の一助となり, 個々の風合い表現がどこに位置付けら れるのか，また，他の表現との関連はどうなっているのかと いった基本的な問題を示すことができる. したがって, 先に 述べた視覚的風合いに対する評価規範が確立していないとい う問題の解決が期待される.

そこで本研究では, 色彩が統一され繊維材料および織組織 が異なる黒色織物を選定し, 視覚的風合いを表現できる多数 の形容語を用いて専門家による視覚的風合い官能評価を行っ た。 そして，3階層に基づく視覚的風合い評価プロセスの客 観的表現を試みるために，階層間の関係について検討した。

\section{2. 視覚的風合い評価プロセスの客観的表現 方法について}

視覚的風合い評価プロセスを客観的に表現するために, 触 知覚的風合いおよび感性工学分野において提案された評価構 造を援用することとした。

触知覚的風合いの評価構造について, 川端 [12]は, まず,

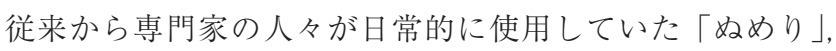
「しゃり」,「こし」のような複合的な意味をもつ用語を重要 な風合い表現として定義した。例えば，「ぬめり」とは細く て柔らかい羊毛の繊維からもたらされる触ってのなめらか さ，しなやかさ，やわらかさの混じった感覚 [12] と定義さ れている。そして, これらの上位の概念に最終的な風合いの 良否があるとする 2 階層の評価構造を示した。さらに，いく つかの物理的特徵量を用いて重要な風合い表現を HV (Hand Value) として数值化し, 最終的な風合いの良否である THV (Total Hand Value) をHVの組み合わせにより数值化する KES システムを確立した.

一方, 最近の感性工学分野の研究成果 [24-26] から, 工業 製品の価值表現には 3 階層の評価構造が適切であることが報 告されている. これらの研究では, 物理量に近い感覚レベル (下位層 ) の評価, それらの情報が複合した認知レベル（中 位層)の評価，ならびに「美しい」「好きな」のような総合 的レベル (上位層) の評価の 3 階層が存在することを示唆し ている

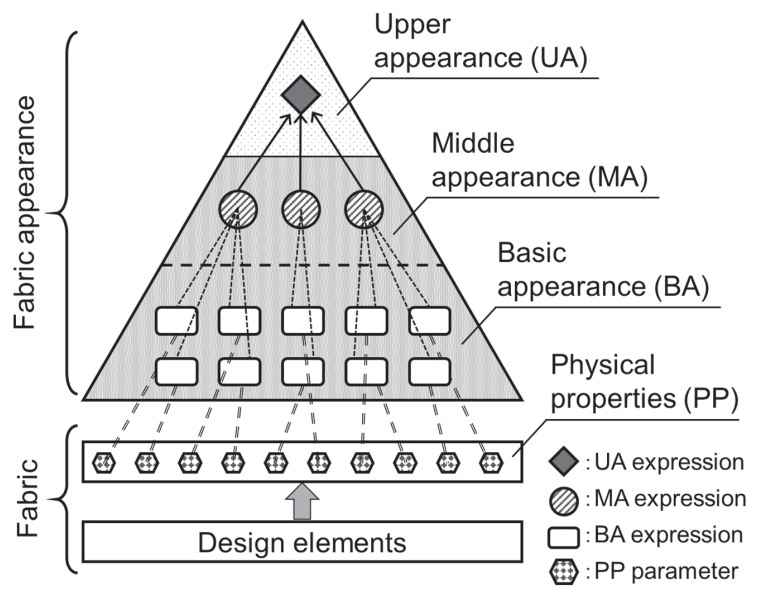

Fig. 1 Assumptive structure for assessment of fabric appearance.

触知覚的風合いの評価構造および感性工学分野の評価構造 に共通することとして，階層間に因果関係を仮定しているこ と, 上位の概念は下位の概念の複合的意味を内包していると いうことが挙げられる.

本研究では，これらの成果を参考にして，Fig. 1示すよう に3 階層に基づく黒色織物における視覚的風合い評価プロセ スの客観的表現を試みた. Fig. 1 は繊維素材, 糸番手や織組 織といった設計要素によって生地の物理的特性が決定され, それが刺激となって 3 階層の視覚的風合いが決定されるまで の過程を示している. なお, 本研究の最終的な目標は, 物理 特性から視覚的風合いを評価することであるが, 本稿では, 3 階層で構成される視覚的風合いを客観的に表現することが 目的であるため, それ以外の関係については検討の対象とし ないこととした。 3 階層の下位層は, 例えば「しなやか」の ように単一的な意味をもつ表現によって構成される基本風合 い(Basic appearance: BA), 上位層は, 審美性・嗜好性・価 值観を意味する表現によって構成される発展風合い (Upper appearance: UA), 中位層は, 基本風合いの複合的意味をもち, 発展風合いの直接的な原因系となる発展規定風合い (Middle appearance: MA) である, 本研究では, 評価プロセスの客観 的表現を以下に示す $2 つ 0$ 手順に従って実施した。 まず，発 展規定風合いと基本風合いの関係を示すために, 基本風合い に関する形容語に対して因子分析を適用し，発展規定風合い 表現を同定した。次に, 発展規定風合いと発展風合いの関係 を示すために, 発展風合いに関する形容語を目的変数, 発展 規定風合い表現を説明変数とした重回帰分析を実施した。

\section{3. 試 料}

本研究では視覚的風合いが重要となる対象を黒色織物に限 定し, その中でも, とりわけ外観の審美性が要求される織物 として婦人用ブラックフォーマル織物を評価対象とした。一 般に婦人用ブラックフォーマルでは, 外観の審美性や高級感 を訴求するため, 特徵的な織組織および光沢のよい繊維素材 が多く用いられる。したがって, これらを評価対象として選 
Table 1 Samples.

\begin{tabular}{|c|c|c|c|c|c|c|c|c|c|c|}
\hline \multirow{2}{*}{$\begin{array}{l}\text { Sample } \\
\text { Symbol }\end{array}$} & \multirow{2}{*}{ Weave } & \multirow{2}{*}{ Fiber material } & \multicolumn{2}{|c|}{ Count [dtex] } & \multicolumn{2}{|c|}{ Density $\left[\mathrm{cm}^{-1}\right]$} & \multirow{2}{*}{ Weight $\left[\mathrm{g} / \mathrm{m}^{2}\right]$} & \multicolumn{2}{|c|}{ Chromaticity } & \multirow[b]{2}{*}{$b^{*}$} \\
\hline & & & warp & weft & ends & picks & & $\mathrm{L}^{*}$ & $a^{*}$ & \\
\hline C_Tr & & Triacetate & 94 & 197 & 91 & 33 & 154 & 17.9 & -0.18 & 0.16 \\
\hline C_Po & Crape & Polyester & 186 & 176 & 51 & 31 & 173 & 17.8 & -0.18 & 0.16 \\
\hline C_Si & & Silk & 53 & 102 & 68 & 40 & 92 & 17.9 & -0.20 & 0.01 \\
\hline$\overline{F \_T r}$ & & Triacetate & 158 & 160 & 89 & 51 & 246 & 18.5 & -0.27 & 0.07 \\
\hline F_Po & Futsu & Polyester & 164 & 180 & 55 & 39 & 237 & 17.4 & 0.32 & -0.47 \\
\hline F_Si & & Silk & 122 & 135 & 43 & 29 & 235 & 18.5 & 0.20 & -0.13 \\
\hline
\end{tabular}

出することにより, 実用的な視覚的風合い評価プロセスの 客観的表現が可能になると考えた。そこで試料は，市販品 の婦人用ブラックフォーマルのために製織された生地として Table 1 に示す色彩 $\left(\mathrm{L}^{*}, \mathrm{a}^{*}, \mathrm{~b}^{*}\right)$ がほぼ統一された黒色織物 を選定した。これらは, 繊維素材 (3 水準：絹 $(\mathrm{Si})$, トリア セテート $(\mathrm{Tr})$ ， ポリエステル $(\mathrm{Po}))$ および織組織 $(2$ 水準 : 梨地織 $(\mathrm{C})$, 風通織 $(\mathrm{F}))$ を要因とした 6 種類である。試料 の表記は, 織組織_繊維素材の順になっており, 例えば梨地 織 (C) ポリエステル (Po) の場合, C Po と表記する。織組 織の選定基準は, 光沢に特徵があることやデザイン性に趣向 を凝らしていることである，繊維素材の選定基準は，光沢が あることとブラックフォーマル用の生地として流通量が多い ことである。また，色彩を統一した理由は，繊維素材および 構造のみを要因とした試料群にするためである。なお, 試料 の色彩は, 色彩色差計 (CR-410, コニカミノルタ社製) を用 いて, 試料表面の異なる 5 箇所を測定し, その平均值を算出 した。

\section{4. 視覚的風合いの官能評価}

\section{1 視覚的風合いに関連する形容語の選定}

視覚的風合い評価に用いる形容語は, 風合いの研究 $[4,5$, $11,19]$ および建築用内装材の視覚的な素材感の研究 [27] を 参照することに加え，専門家に対する聞き取り調査を経て決 定した。この理由は, 消費者や生産者が黒色織物に対して感 じる様々な視覚的印象やそれを形容する表現は, 製造現場の 専門家にフィードバックされ，蓄積されていると考えたため である，上記の形容語選定を経ることで，視覚的風合い評価 に関する多角的観点を網羅できると考えられる基本風合いに 関する形容語 (23 種類) と発展風合いに関する形容語 (4 種 類 ）を選定した。Table 2 に選定した形容語を示す。

\section{2 視覚的風合い官能評価方法}

川端［1］は，風合いの定義やその判定基準を明らかにする ためには，材料の物理的特性と使用時の消費特性を熟知して いる人が真の風合い判定者であるとしている。 そこで被験者 は，上記を満たす専門家として官能評価を実施した時点にお いてブラックフォーマルの開発・設計・製造・流通・販売の いずれかに従事し， 8 年以上の従事経験を有する者（13 名） とした

官能評価は一対比較法 (中屋の変法) [28］を採用した。被 験者は, ${ }_{6} \mathrm{C}_{2}=15$ の試料対を観察し, 各形容語について 5 段 階の尺度を用いて評価した。例えば，試料対 A と B を「艶 やかな」について比較評価する場合, +2 ：Aの試料は, Bの 試料に比べて, 非常に「艶やかな」, $+1 ： \mathrm{~A} の$ 試料は, Bの 試料に比べて, やや「艶やかな」, 0：どちらともいえない, $-1: \mathrm{B}$ の試料は A の試料に比べて，やや「艶やかな」, -2 : $\mathrm{B}$ の試料は A の試料に比べて, 非常に「艶やかな」のいずれ かにマークすることとした。 なお，評価時間は設定せず，被 験者には評価できるまで試料対を観察することや反復評価を 認めた

実験は，被験者に対して一定の照明環境を提示するた めに, Fig. 2 に示すような標準光源 D65を備えたボックス (CAC120K, Intec 社製) のみ光源とする暗室内で実施し た。これは織物の反射特性に異方性があり，照明が織物に入 射する方向や被験者が織物を観察する方向 (受光する方向 ) によってその反射特性が異なるため, 一意的な照明環境を構 


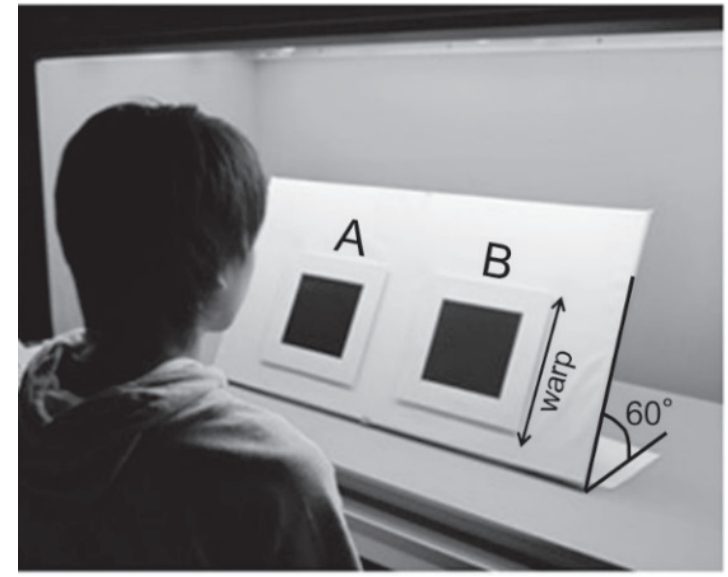

Fig. 2 Experimental environment and conditions.

築する必要があると考えたためである、試料設置条件は, 光 源の入射角が $60^{\circ}$ となる試料台の上に試料のたて糸方向が試 料台の水平方向に対して直交するように設置した，被験者の 観察条件は，観察距離 $500 \mathrm{~mm}$, 観察角度 $0^{\circ}$ とした。ただし， 触知覚が評価結果に影響を及ぼさないよう，提示された試料 対に手を触れないことを指示した。なお，試料台表面におけ る照度はデジタル照度計 (IM-3, トプコン社製) を用いて測 定した結果 9201x（試料台 3 箇所の平均值）であった。

\section{3 官能評価結果}

\section{（1）被験者群内の判断基準の一致性}

得られた官能評価結果を基に，一致性の係数 $u$ [29] を全形 容語について算出した。結果を Fig. 3 に示す。一致性の係数 $u$ は，被験者を 2 人ずつの組にしたときの判断が一致してい

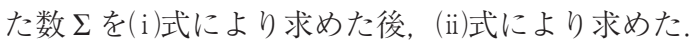

$$
\begin{array}{r}
\Sigma={ }_{n} C_{2} \times{ }_{k} C_{2}-\sum_{j>i} x_{i j} \times\left(n-x_{i j}\right) \\
u=2 \Sigma /\left({ }_{n} C_{2} \times{ }_{k} C_{2}\right)-1
\end{array}
$$

$u$ : coefficient of consistency

$i, j$ : sample number

$x_{i j}$ : number of persons who evaluated 'sample i was superior than sample j'

$n$ : number of persons

$k$ : number of samples

ただし, $n$ は被験者の数, $k$ は試料の数, $x_{i j}$ は試料 $A_{i}$ と $A_{j}$ を比較した時に $A_{i} \geqq A_{j}$ と評価した人数を示す。また, 一致 性の係数 $u$ は被験者 $n$ 人の判定が完全に一致しているとき 1 となる. $X^{2}$ 検定より $u>0.06$ のとき有意水準 $5 \%$ で被験者群 内の評価基準が一致していたことを示す．Fig. 3 より全形容 語おいて被験者の判断に一致性が認められ, 個々の視覚的風 合い表現について被験者間で共通の判断基準が存在すること がわかった。

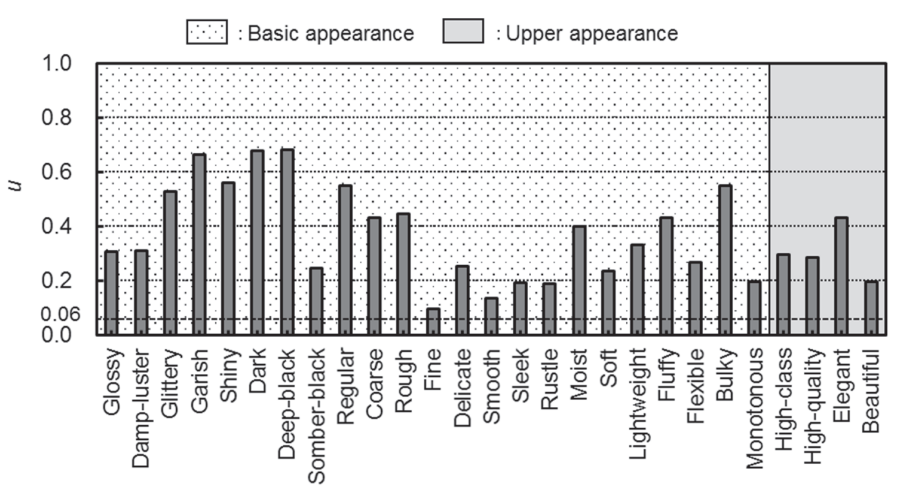

Fig. 3 Coefficient of consistency on assessment of subjects.

\section{(2) 形容語の有意性}

被験者の判断に一致がみられたことから各試料に対する評 価値として平均嗜好度を算出した。 各試料の平均嗜好度は(iii) 式に基づき, 全形容語について算出した。 結果を Table 3 に 示す.

$$
\hat{\alpha}_{i}=\frac{1}{n k} x_{i .}
$$

$\hat{\alpha}:$ mean preference

$i$ : sample number

$x_{i .}:$ sum of the scores for sample $\mathrm{i}$ of all persons ' $i$ was superior than sample $j$

$n:$ number of persons

\begin{tabular}{|c|c|c|c|c|c|c|c|}
\hline \multirow{2}{*}{ Layer } & \multirow{2}{*}{ Adjectives } & \multicolumn{6}{|c|}{ Sample } \\
\hline & & C_Tr & C_Po & C_Si & $\mathrm{F} \_\mathrm{Tr}$ & F_Po & F_Si \\
\hline \multirow{23}{*}{$\begin{array}{l}\text { Basic } \\
\text { appearance }\end{array}$} & Glossy & 0.24 & 0.15 & -0.12 & 0.19 & -0.23 & -0.24 \\
\hline & Damp-luster & 0.22 & 0.09 & -0.01 & 0.22 & -0.22 & -0.29 \\
\hline & Glittery & 0.15 & -0.01 & -0.06 & 0.09 & -0.13 & -0.04 \\
\hline & Garish & 0.05 & -0.03 & 0.01 & -0.14 & -0.13 & 0.23 \\
\hline & Shiny & 0.00 & -0.05 & 0.01 & -0.14 & -0.08 & 0.26 \\
\hline & Dark & 0.18 & 0.51 & -0.37 & 0.69 & -0.22 & -0.79 \\
\hline & Deep-black & 0.21 & 0.50 & -0.41 & 0.68 & -0.15 & -0.82 \\
\hline & Somber-black & -0.22 & -0.26 & 0.33 & -0.45 & 0.09 & 0.50 \\
\hline & Regular & -0.05 & 0.37 & -0.14 & 0.32 & 0.01 & -0.51 \\
\hline & Coarse & 0.32 & -0.04 & 0.06 & -0.27 & -0.06 & -0.01 \\
\hline & Rough & 0.40 & 0.10 & 0.09 & -0.26 & -0.01 & -0.32 \\
\hline & Fine & -0.10 & 0.14 & 0.21 & 0.05 & -0.17 & -0.13 \\
\hline & Delicate & -0.09 & 0.27 & 0.27 & 0.01 & -0.26 & -0.21 \\
\hline & Smooth & -0.19 & 0.00 & 0.09 & 0.22 & 0.00 & -0.12 \\
\hline & Sleek & -0.10 & -0.17 & -0.13 & 0.04 & 0.09 & 0.27 \\
\hline & Rustle & -0.21 & 0.18 & -0.19 & 0.08 & 0.10 & 0.04 \\
\hline & Moist & 0.08 & 0.10 & 0.01 & 0.23 & -0.14 & -0.28 \\
\hline & Soft & 0.03 & 0.00 & 0.12 & 0.08 & -0.10 & -0.12 \\
\hline & Lightweight & -0.10 & 0.03 & 0.04 & -0.19 & 0.04 & 0.19 \\
\hline & Fluffy & 0.12 & 0.05 & 0.08 & 0.04 & -0.18 & -0.10 \\
\hline & Flexible & -0.13 & 0.01 & 0.19 & 0.12 & -0.13 & -0.06 \\
\hline & Bulky & 0.14 & 0.00 & 0.15 & 0.09 & -0.21 & -0.18 \\
\hline & Monotonous & -0.18 & -0.13 & -0.17 & 0.12 & 0.19 & 0.17 \\
\hline \multirow{4}{*}{$\begin{array}{l}\text { Upper } \\
\text { appearance }\end{array}$} & High-class & 0.04 & 0.29 & 0.09 & 0.29 & -0.32 & -0.40 \\
\hline & High-quality & 0.09 & 0.28 & 0.04 & 0.26 & -0.31 & -0.36 \\
\hline & Elegant & 0.01 & 0.21 & 0.04 & 0.09 & -0.18 & -0.17 \\
\hline & Beautiful & 0.10 & 0.22 & 0.01 & 0.21 & -0.23 & -0.31 \\
\hline
\end{tabular}

$k:$ number of samples

Table 3 Mean preference of samples. 


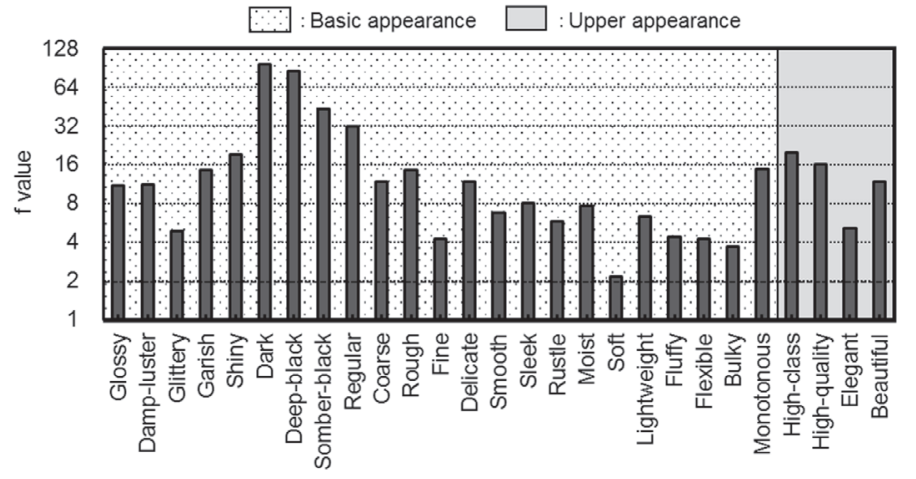

Fig. 4 Variance ratio concerned with main effect on sensory assessment.

ただし, $\hat{\alpha}_{i}$ は試料 $A_{i}$ における平均嗜好度, $n$ は被験者の数, $k$ は試料の数, $x_{i .}$ は被験者全員の試料 $A_{i}$ に対する評点の合計 である。分散分析より, 分散比 $\mathrm{f}>1.90$ のとき有意傾向 $(\mathrm{p}<$ 0.10）の主効果が認められる。したがって，Fig. 4 に示すよう に，全形容語において有意傾向の主効果が認められた。すな わち, 専門家は 6 種類の試料に対して異なる印象をもって評 点を与えたことがわかった。 さらに, Table 3 より,「艶やか な (Glossy)」に着目すると, 梨地織でトリアセテートの試料 (C_Tr) が最も評価が高く, 風通織で絹の試料 (F_Si) が最も 評価が低くなった。一方，「ギラッキがある (Garish)」に着 目すると, 風通織で絹の試料 ( F_S Si) が最も評価が高く, 風 通織でトリアセテートの試料 (F T T r ) が最も評価が低くなっ た。これらの形容語はいずれも試料表面の光反射に起因する 明るさ感の評価項目であるが，これらの評価は異なる判断基 準によって行われたものと推察される.

\section{5. 視覚的風合い評価プロセスの客観的表現}

\section{1 発展規定風合いと基本風合いの関係}

3 階層の中位層である発展規定風合いを表現するために, 基本風合いの官能評価結果に対して因子分析を適用した。

\section{(1) 因子分析方法 [30]}

因子分析の観測変数は, 基本風合いに関する形容語 23 種 類の平均嗜好度 (Table 3 参照) とし, 主因子法を適用した. 固有值が 1 以上かつ固有值のスクリープロットがなだらかに なる直前までの条件を満たすこととした，因子の解釈基準は， 抽出する因子数を決定した後に, 斜交回転 (プロマックス法) を適用し, 因子負荷量の絶対值が 0.6 以上の形容語を解釈に 採用した。なお，斜交回転を採用した理由は，斜交回転が因 子間の相関を仮定するモデルであり，柔軟なモデリングが可 能であるためである。また，抽出された因子に対してそれぞ れ因子得点を算出した。

\section{(2) 因子分析結果および考察}

Fig. 5 に固有值のスクリープロットを示す。因子抽出基準
Table 4 Factor loadings.

\begin{tabular}{l|r|rrr}
\hline Adjective & \multicolumn{1}{c}{ F1 } & F2 & F3 & F4 \\
\hline Shiny & 0.93 & -0.06 & 0.05 & -0.05 \\
Garish & 0.92 & -0.04 & 0.21 & 0.08 \\
Somber-black & 0.85 & 0.22 & -0.43 & 0.01 \\
Regular & -0.97 & 0.09 & -0.06 & 0.06 \\
Deep-black & -0.88 & -0.08 & 0.31 & 0.00 \\
Dark & -0.84 & -0.03 & 0.33 & -0.03 \\
Rustle & -0.63 & -0.25 & -0.47 & -0.35 \\
Flexible & 0.20 & 1.04 & 0.07 & -0.42 \\
Fine & -0.03 & 1.00 & -0.15 & 0.04 \\
Delicate & -0.09 & 0.91 & -0.18 & 0.25 \\
Soft & -0.01 & 0.77 & 0.41 & -0.02 \\
Glittery & -0.03 & -0.25 & 1.05 & -0.04 \\
Glossy & -0.48 & -0.06 & 0.67 & 0.16 \\
Damp-luster & -0.43 & 0.14 & 0.66 & 0.11 \\
Lightweight & 0.57 & 0.05 & -0.67 & 0.16 \\
Rough & -0.25 & -0.10 & -0.06 & 1.00 \\
Coarse & 0.35 & -0.22 & 0.14 & 0.87 \\
Monotonous & -0.05 & -0.46 & -0.09 & -0.75 \\
Sleek & 0.44 & -0.46 & 0.14 & -0.70 \\
Smooth & -0.33 & 0.64 & -0.04 & -0.68 \\
Moist & -0.58 & 0.30 & 0.46 & -0.04 \\
Bulky & 0.05 & 0.56 & 0.59 & 0.17 \\
Fluffy & 0.05 & 0.47 & 0.59 & 0.29 \\
\hline
\end{tabular}

より，第 4 因子まで抽出されたことから，4つの因子によっ て発展規定風合いが構成されることがわかった，次に，Table 4 に示す斜交回転後の基本風合いに関する形容語の因子負荷 量から各因子がもつ意味を解釈した。第 1 因子 (F1) は,「光 りすぎている (Shiny)」, 「ぎらつく(Garish)」,「くすみがあ る (Somber-black)」の負荷量が正に大きかった，同様に，第 3 因子 (F3) は,「きらめく (Glittery)」,「艶やかな (Glossy)」, 「しっとりした艶 (Damp-luster)」の負荷量が正に大きかった. これらはいずれも明るさに関連した形容語であるが，相対的 に前者は布の全体的 (巨視的) 範囲の明るさを表し，後者は 布の部分的 (微視的) 範囲の明るさを表していると考えられ る。したがって，F1 を巨視的な明るさ感，F3 を微視的な明 るさ感と解釈した。第 2 因子 (F2) は「きめ細かい (Fine)」,「纎 細な (Delicate)」のような表面の粗さに関連した形容語に加 えて「しなやか (Flexible)」,「やわらかい (Soft)」のような 表面の硬さに関連する形容語の負荷量が正に大きかった。し たがって，F2 を硬軟感と解釈した。ただし，一般に表面の 硬さは実際に手を触れることで評価されるものであるが，本 実験における官能評価では, 試料に手を触れないことを条件

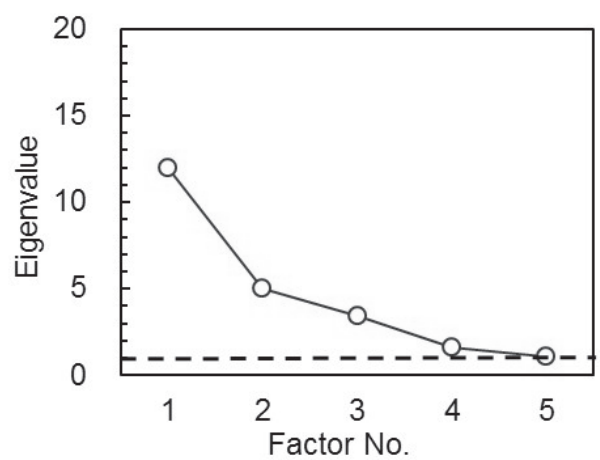

Fig. 5 Eigenvalue concerned with factor analysis. 
Table 5 Factor score.

\begin{tabular}{lcccccc}
\hline \multirow{2}{*}{ Middle appearance } & \multicolumn{5}{c}{ Sample } \\
\cline { 2 - 6 } & C_Tr & C_Po & C_Si & F_Tr & F_Po & F_Si \\
\hline F1 & 0.12 & -1.06 & 0.59 & -1.09 & -0.10 & 1.54 \\
'Macroscopic brightness sensation' & & & & & & \\
F2 & -0.65 & 1.89 & 0.74 & 0.29 & -2.18 & -0.09 \\
'Softness sensation based on the roughness' & & & & & & \\
F3 & 1.69 & -1.50 & 0.49 & 1.07 & -0.31 & -1.44 \\
'Microscopic brightness sensation' & & & & & & \\
'Ro & 1.27 & 1.63 & -0.11 & -1.36 & -1.36 & -0.07 \\
\hline
\end{tabular}

としたため, 被験者は視覚で捉えた表面の状態を根拠に推定 された硬軟感であると考えられる。第 4 因子 (F4) は，「凹凸 感がある (Rough)」,「ざらついた (Coarse)」, の負荷量が正 に大きかった。これらはいずれも表面の粗さに関連した形容 語である。したがって，F4 を粗滑感と解釈した。

以上より，視覚的風合いの発展規定風合い表現として, 明 るさに関する因子 (F1，F3)，硬さに関する因子 (F2)，粗さ に関する因子 (F4) が存在することがわかった。建築内装材・ 外装材などの視覚的な素材感を対象とした研究において, 明 るさ, 粗さ, 硬さを表す因子が抽出されていることが報告 $[27$, $31,32]$ されており, 黒色織物を対象とした本研究もこれら に一致した結果となった。

次に, Table 5 に因子得点の結果を示す. 巨視的な明るさ 感 (F1) に着目すると, 風通織で絹の試料 (F_Si) が最も得点 が高く, 風通織でトリアセテートの試料 (F_Tr $)$ が最も得点 が低くなった。一方, 微視的な明るさ感 (F3) に着目すると, 梨地織でトリアセテートの試料 (C_Tr) が最も得点が高く, 梨地織でポリエステルの試料 (C_Po) が最も得点が低くなっ た。これらの結果から，明るさに関する因子が 2 因子抽出さ れた理由について考察すると, 以下の点が挙げられる. 本研 究では, 織物と照明環境の幾何学的関係を一意に統制するこ とで, 被験者間の評価のばらつきを抑制できると考え, 観察 条件を設定した。一方で, この観察条件に起因して, 織物表 面に照明の映り込みや, 織物を構成する浮き糸部分において 局所的な反射が生じていたと考えられる。このように，観察 対象内に強い反射光が存在する場合, 観察の状態によって印 象が変化しやすいことが報告されている [33]. すなわち, 被 験者が試料を観察する際に着眼する領域が形容語によって異 なっており，巨視的な明るさ感，微視的な明るさ感のような 反射領域を反映した因子が抽出されたものと考察される.

\section{2 発展規定風合いと発展風合いの関係}

3 階層の上位層である発展風合いと中位層の発展規定風合 いの関係を明らかにするために, 重回帰分析を実施した。

(1) 重回帰分析方法 [34]

発展風合いに関する 4 種類の形容語間の相関係数を算出し た結果, すべての形容語間に $1 \%$ 有意の相関関係があること がわかった。すなわち, これらの形容語は同一の判断基準で
評価されたといえる，そこで，重回帰分析の目的変数には， 発展風合いに関する 4 種類の形容語のうち主効果の分散比 $\mathrm{f}$ 值が最大 (Fig. 4 参照) であった「高級な (High-class)」の平 均嗜好度を, 説明変数には発展規定風合い表現の因子得点 (Table 5 参照) をそれぞれ採用した。变数選択には变数増減 法を適用した。

\section{(2) 重回㷌分析結果および考察}

重回帰分析によって得られた回帰式を(iv)式に示す。

$\mathrm{UA}=-0.15 \times \mathrm{F} 1+0.14 \times \mathrm{F} 2+0.10 \times \mathrm{F} 3$

UA : Mean preference of 'High-class'

F1 : Factor score of 'Macroscopic brightness sensation'

F2 : Factor score of 'Softness sensation based on the roughness'

F3 : Factor score of 'Microscopic brightness sensation' 回帰式を基に算出された発展風合い（高級な）の計算值と官 能評価結果の実測值を Fig. 6 に示す。両者の当てはまりの良 さを表す決定係数は $\mathrm{R}^{2}=0.99$ であり, 高度に有意 $(\mathrm{p}<0.01)$ な回帰式を得たことから発展規定風合いと発展風合いの間に 因果関係が成り立つことが示された。

また, 回帰式おける各説明変数の目的変数への相対的な影 響力の強さを表す標準偏回帰係数は, それぞれ F1 が-0.51, F2 が0.66, F3 が0.42であった。すなわち, 巨視的な明るさ 感 $(F 1)$, 硬軟感 $(F 2)$, 微視的な明るさ感 $(F 3)$ がほぼ同程度

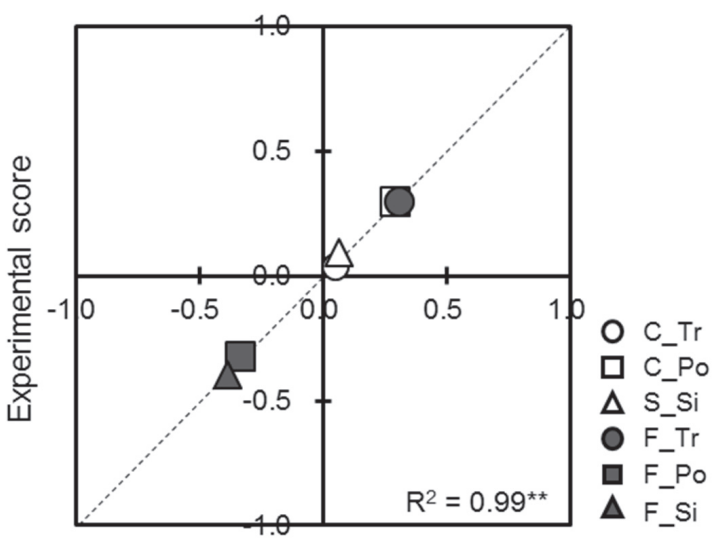

Calculated score

Fig. 6 Relationship between experimental score and calculated score concerned with "High-class". 
に影響していると考えられるため, 発展風合いは, 複数の発 展規定風合い表現のいずれの因子にも影響を受けていること がわかった。ささらに, 標準偏回帰係数の符号から優れた発展 風合いを有する黒色織物は，「ギラツキ」等の巨視的な明る さ感が小さく,「やわらかい」等の硬軟感が大きく,「艶やか」 等の微視的な明るさ感が大きい特性をもつ織物であることが わかった。 なお，本研究で用いた試料群では C_Po や F_Tr が これに該当した。

\section{6. まとめ}

本研究では, 視覚的風合いの体系化の第一段階として, 黒 色織物における視覚的風合いの評価プロセスを客観的に表現 することを目的に, 専門家による官能評価を行い, 3 階層に 基づく評価プロセスの客観的表現を試みた.

その結果, 3 階層における中位層の発展規定風合いは, 巨 視的な明るさ感, 硬軟感, 微視的な明るさ感, 粗滑感の 4 因 子で表現された。また, 上位層の発展風合いは, 巨視的な明 るさ感が消極的 $(-)$, 硬軟感と微視的な明るさ感が積極的 $(+)$ に関与することが明らかになった。

これらの結果より，3階層間の関係が明らかになり, 黑色 織物における視覚的風合い評価プロセスを客観的に表現する ことができた。今後は, 評価対象や評価者の属性が異なる条 件において官能評価を実施することで評価プロセスを視覚的 風合いの評価構造としてモデル化するとともに, 視覚的風合 いの客観的評価法の確立を目指して基本風合いと布の物理的 特性の関係について検討することが必要である。

\section{謝 辞}

本研究にあたりまして, 試料のご提供を頂きました三菱レ イヨン株式会社の関係各位に深謝申し上げます。また, 本研 究の一部は, 独立行政法人科学技術振興機構 (JST)「平成 20 年度シーズ発掘試験 (06-026)」の助成を受けて行ったもので ある。

\section{References}

[1] Kawabata S (1972) Kogyo, 5, 277-285

[2] Matsuo T (1972) Kogyo, 5, 291-298

[3] Kobayashi S (1973) Sen'i Kikai Gakkaishi, 26, 88-94

[4] Hoffman RM, Beste LF (1951) Text Res J, 21, 66-77

[5] Brand RH (1964) Text Res J, 34, 791-804

[6] Binns H (1926) J Text Inst, 17, T615

[7] Saito M, Harada T (1987) Sen'i Kikai Gakkaishi, 40, 239-245

[8] Kobayashi S, Suda N (1966) J Jpn Res Assoc Text End-uses, 7, 290-296
[9] Kobayashi S (1967) J Jpn Res Assoc Text End-uses, 8, 264270

[10] Matsuo T (1970) Sen'i Kikai Gakkaishi, 23, T134-T143

[11] Harada T, Saito M, Matsuo T (1971) Sen'i Kikai Gakkaishi, 24, T126-T138

[12] Kawabata S (1980) "The Standardization and Analysis of Hand Evaluation, 2nd ed, Hand Evaluation and Standardization Committee", Text Mach Soc Jpn

[13] Peirce FT (1930) J Text Inst, 21, T377-T416

[14] Kawabata S (1969) Sen'i Gakkaishi, 25, 191-199

[15] Kitazawa S, Susami K (1968) Sen'i Kikai Gakkaishi, 21, T21-T28

[16] Howorth WS (1964) J Text Inst, 55, T251

[17] Shinohara A (1960) Hinshitsukanri, 11, 711

[18] Matsuo T (1963) J Text Mach Soc (predecessor journal of J Text Eng), 16, 513-524

[19] Kanai H, Morishima M, Nasu K, Nishimatsu T, Shibata K, Matsuoka T (2011) Text Res J, 81, 1216-1225

[20] Sawaji M (1960) OYOBUTURI, 29, 698-704

[21] Gunji T, Nihira K, Tsuboi T (1970) Sen'i Kikai Gakkaishi, 24, T33-T41

[22] Aratani Y (1972) Sen'i Kikai Gakkaishi, 25, 713-720

[23] Kanai H, Kimura H, Morishima M, Shouji U, Nishimatsu T, Shibata K, Yamamoto T (2012) Text Res J, 82, 1982-1995

[24] Nishina K, Nagata M, Maeda M (1998) Japanese J Ergon, 34, 258-259

[25] Tagawa T, Tsuchiyama E (2002) J Jpn Soc Kansei Eng, 2, 2734

[26] Konishi S, Nonaka H, Kurihara M (2008) J Jpn Soc Fuzzy Theory Intell Inform, 20, 141-149

[27] Maki K, Akamatsu M, Satake A (2007) J Environ Eng, 614, $17-23$

[28] Research Committee of Sensory Evaluation (1973) "Sensory evaluation handbook", pp366-385, Union of Japanese Scientists and Engineers, Tokyo

[29] Sato S (1985) "TOUKEITEKI KAN'NOUKENSASHUHOU", 362pp, JUSE Press, Ltd., Tokyo

[30] Yanai H, Shigemasu K, Maekawa S, Ichikawa M (1990) "Inshi bunseki", 280pp, Asakura Publishing, Tokyo

[31] Kitaura K (1976) Trans Architect Inst Jpn, 241, 153-164

[32] Okajima T, Wakayama S, Enya M, Watanabe T (1989) J Struct Constr Eng, 401, 1-10

[33] Okajima T, Wakayama S, Noda K, Kikuchi S (1988) J Struct Constr Eng, 384, 42-49

[34] Okuno T (1991) "Multivariate analysis, 2nd ed", pp54-56, Union of Japanese Scientists and Engineers, Tokyo 